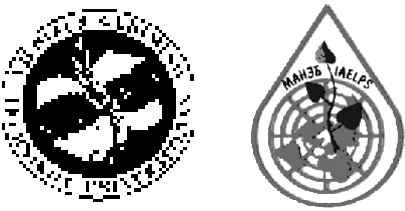

\title{
AIR POLLUTION AT PARKING-LOTS OF VILNIUS
}

\author{
Pranas Baltrẻnas, Danguolẻ Kaziukonienė, Mindaugas Kvasauskas
}

\author{
Dept of Environmental Protection, Vilnius Gediminas Technical University, \\ Sauletekio al. 11, LT-10223 Vilnius-40, Lithuania.E-mail: aak@ap.vtu.lt
}

Recievied 25 Sep 2003; accepted 3 Oct 2003

\begin{abstract}
The expansion of Vilnius creates the need for the installation of new parking facilities. This problem could be solved by establishing guarded parking-lots or modern underground and multi-storey garages, in order to economize useful land and comply with the requirements of environmentalists.

Investigation was carried out on parking-lots of Vilnius. All the guarded parking-lots are divided into three types in accordance with the size of the lot and the type of vehicles parked on it. Measurements were carried out at a lot of each type. The concentrations of hydrocarbons, nitric oxide, carbon monoxide and dust were measured.

Guarded parking-lots located at the crossroad of Ateities and L. Giros streets, on Architektu and Č. Sugiharos streets were selected for the investigation. The parking-lot located at the crossroad of Ateities and L. Giros streets had the highest concentration of nitric oxide overrunning the permitted concentration up to 1,9 times. Besides, the concentration of carbon monoxide and hydrocarbons also overran the permitted norms. The lowest concentrations were found after measuring dust concentration in the air.
\end{abstract}

Keywords: air pollution, mobile pollution sources, carbon monoxide, nitric oxide, hydrocarbons, dust.

\section{Introduction}

As demonstrated by the statistical data, transport is one of the main factors having an impact on the air quality and climate change all over Europe. Transport has the heaviest impact on the air through the emission of nitric oxides, carbon monoxide, and volatile organic compounds (VOC). Industrial emissions are found in higher layers of the atmosphere, where they get dispersed over a large area, meanwhile transport gas emissions may concentrate in the layer close to the ground and, thus, has a direct impact on human health [1].

The number of vehicles is the main indicator defining the agents. During the last 5 years of the last century, the number of cars recorded at the Traffic Police went up by about $40 \%$. Obviously, their certain part is not continually maintained. Thus, the real situation is reflected by the volume of transport fuel. From 1996 to 2000 the number of cars rose by about $49 \%$. The number of cars older than 10 years was 1055,7 thousand, and it accounted for about $90 \%$ of the total number of cars. In 1997 the number of such cars was $84 \%$ in Lithuania, and $80 \%$ and $71 \%$ in Latvia and Estonia, accordingly. Although the number of maintained cars has gone up in Lithuania, the total volume of consumed fuel has gone down by $6 \%$. This reveals that the use of vehicles has become more efficient [2].

In Lithuania, like in most countries, mobile pollution sources are the main source of emission into the atmosphere. In 2000 road transport accounted for the main part of emissions, i e $97 \%$, and other vehicles (railway, ships, aircraft, etc) account only for $3 \%$.

The structure of pollutants has remained similar to that of the previous years. The greatest share falls to carbon monoxide $(\mathrm{CO})-73,8 \%$, nitric oxides $-13,2 \%$ and volatile organic compounds (VOC) - 12,9\% [3].

In 2000 dieseline accounted for the biggest share of fuel used for vehicles - approximately $50 \%$. In 2000 the use of liquefied gas in transport increased by $76 \%$, compared with 1996. Although the number of cars has increased in Lithuania, the total volume of the consumed fuel has fallen by $6 \%$, compared with 1996 . Reduction in the total amount of the fuel consumed was followed by reduction in emissions from mobile pollution sources [4].

Of all the environmental components, the atmosphere is most affected by pollution. The atmosphere is polluted with gas emissions, dust caused by tire wear, pavement wear and wear of vehicle construction elements. 
Burning transport fuel emits carbon monoxide (80\%), hydrocarbons $(15 \%)$, nitric oxides $(5 \%)$ and inconsiderable amounts of lead, benzopyrene and other toxic materials.

Compared with industrial enterprises, it is hardly possible to catch toxic substances emitted from vehicles (especially if they do not have neutralizers), thus they are emitted into the atmosphere.

Car engine oxides contain 280 components that by their impact on human health are divided into non-toxic $\left(\mathrm{N}_{2}, \mathrm{O}_{2}, \mathrm{CO}_{2}, \mathrm{H}_{2} \mathrm{O}, \mathrm{H}_{2}\right)$ and toxic $\left(\mathrm{CO}, \mathrm{CH}, \mathrm{NO}_{\mathrm{X}}, \mathrm{SO}_{2}\right.$, $\mathrm{H}_{2} \mathrm{C}, \mathrm{C}$, aldehydes, etc).

These components react with one another and with atmosphere components and produce new toxic materials: sulphates, nitrates, ozone, acids, photo-oxidants, etc.

Toxic materials pollute not only the site on which cars are parked but a much bigger area. The area depends on the geographical position of parking facilities, on relief, meteorological conditions, the urbanization level of the area (building density and height) [5].

With an annually increasing level of motorization, Vilnius encounters a growing problem related to car parking. This problem is especially acute for those living and working in the downtown of Vilnius [6]. At present, the car-parking problem is being solved by building underground parking facilities right in the downtown, under its squares and buildings.

With the expansion of Vilnius, the need for new parking-lots is continually growing. Due to the expansion of the city, metal garages covering vast areas and spoiling the landscape will be removed. It will be necessary to build new facilities for car parking. This problem could be dealt with by building guarded parkinglots or underground or multi-storey garages using less useful land space and complying with environmental requirements.

As at present a lot of cars are parked on guarded parking-lots, it is important to analyze the existing network of such facilities in Vilnius as well as to determine the surrounding environment.

The investigation was aimed at estimation and evaluation of the level of atmosphere pollution at parkinglots of Vilnius.

\section{Investigation methods}

The total concentration of hydrocarbons was determined with the help of the method of chromatographic analysis.

The methods were used for the determination of the concentration of aliphatic $\mathrm{C} 1-\mathrm{C} 8$ and aromatic C6-C8 hydrocarbons. The measuring range was $50-30000 \mathrm{mg} / \mathrm{m}^{3}$.

Conditions for chromatographic analysis:

Chromatographic column: a glass (length $3 \mathrm{~m}$, diameter $2 \mathrm{~mm}$ ) filled with $15 \%$ carbowax 1500 put on a chromatogrophe N - AW;
Thermostat temperature $100{ }^{\circ} \mathrm{C}$;

Temperature of a gas detector and evaporator $200{ }^{\circ} \mathrm{C}$; Gas carrier (nitrogen) flow velocity $23 \mathrm{ml} / \mathrm{min}$; Hydrogen flow velocity $21 \mathrm{ml} / \mathrm{min}$;

Air flow velocity $200 \mathrm{ml} / \mathrm{min}$.

A sample was taken into glass pipettes. At the same time, the temperature and pressure of the emitted gas were measured. The sample, when brought, was analysed with the help of a gas chromatograph with the flame ionization detector ЦВET-500M.

The total concentration of hydrocarbons was determined by using a calibration diagram in which the peak height depended on hexane concentration recalculated into carbon atoms by the method of absolute calibration.

The sample was put into the gas chromatograph with a medical syringe. The sample was chromatographed 5 times. The total concentration of hydrocarbons $\left(\mathrm{C} \mathrm{mg} / \mathrm{m}^{3}\right)$, recalculated into carbon atom number in the sample was determined from the calibration diagram, taking into consideration peak heights.

A photometric method was used for the determination of nitric oxide concentration.

For the analysis, the air was being drawn in for 5 minutes with an aspirator at a speed of $0,21 / \mathrm{min}$ through two absorption vessels filled with $10 \mathrm{ml} 8 \%$ $\mathrm{KJ}$ solution.

The sample brought was analysed with the photocolorimeter $K F K-2 M P$. The optic density was measured with the wavelength equal to $520 \mathrm{~nm}$. Taking into consideration the obtained values, nitric dioxide concentration, $\mu g$, was determined form the calibration curve.

Carbon monoxide concentration in the air was determined by taking the air samples into a ball chamber and proceeding their analysis with the potentiometric gas analyzer Паладий-3. This device was used for measuring carbon monoxide (CO) in the atmosphere and in the air of production premises. The mixture of the gas analysed should not contain hydrogen gas. The measuring range of the device is $0-50 \mathrm{mg} / \mathrm{m}^{3}$, its error does not exceed $0,375 \mathrm{mg} / \mathrm{m}^{3}$ when the concentration of the gas measured is $0-3 \mathrm{mg} / \mathrm{m}^{3}$ and does not exceed $0,75 \mathrm{mg} / \mathrm{m}^{3}$ when gas concentration is $3-10 \mathrm{mg} / \mathrm{m}^{3}$. The readings of the device are proportional to the strength of the current that is generated during carbon monoxide (CO) oxidation on a working electrode.

Dust concentration was determined with the help of weighted (gravimetric) method.

The $A \Phi A-B \Pi$ filter was used for the determination of dust concentration. The air analysed was being drawn in for 10 minutes through an aspirator at the a speed of $20 \mathrm{l} / \mathrm{min}$.

Before the analysis the filters weighed on an analytical scale were kept in a desiccator for 1 hour. The filters brought for the analysis were kept in a desiccator for 24 hours, then 2 hours prior to weighing they were kept in the premises of weighing. The weighing of the 
filters was followed by dust concentration calculations.

Taking air samples for analysis, a different number and layout of measuring points were selected at different parking facilities. That depended on various factors: the relief of a location, the size of facilities, their configuration, and the intensity of car mobility in the facilities. Mostly, the number of measuring points depended on the size of the facilities at which air pollution measuring was carried out - the bigger the area, the greater the number of measuring points.

\section{Results}

All guarded and biggest parking-lots are divided into certain types in accordance with the type of vehicles parked on them and the size of a lot. By vehicle types, the lots are divided into two types: for light-vehicle parking and for heavy and special vehicle parking. By the size, parking-lots are divided into 3 types: for up to 50 vehicles, 50-100 vehicles and for more than 100 vehicles. Each type of lots was chosen for measurements.

The guarded parking-lot located at the crossroad of Ateities and L. Giros streets (Fig 1), intended for light, cargo and special vehicles, was chosen as it was at the closest distance from residential multi-storey houses, administrative buildings and might have the nearest impact on the environment and human beings.

Location of the parking-lot. On the northern side, a 5 -storey residential building is located 20 meters away from the facilities. This side of the facilities is planted with trees. On the eastern side, administrative buildings are located close to the facilities. On the southeastern

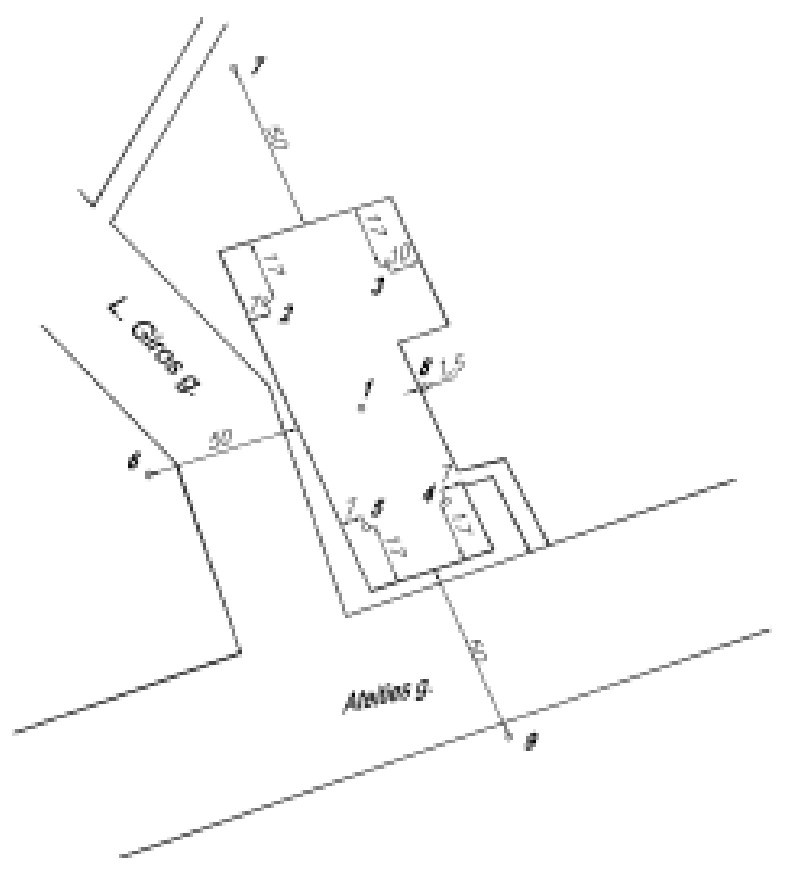

Fig 1. Guarded parking-lot at Ateities and L.Giros str crossroad side, Ateities street is located with a grove on the other side of the street. On the southwestern side, a school is located 150 away from the facilities. The western and northern sides neighbour upon L. Giros street. On the western side, multi-storey residential buildings are located 40 meters away from the facilities. Further, private residential houses are located along L. Giros street.

Measurements were taken at 6 points. They were taken in series; at each point measurements were taken three times. A break of 20-30 minutes was taken between the series. Almost at all the points concentrations overran the permitted norms set in hygiene requirements with regard to the ambient air. Fig 2 shows the extent at which materials overran the permitted concentrations [4].

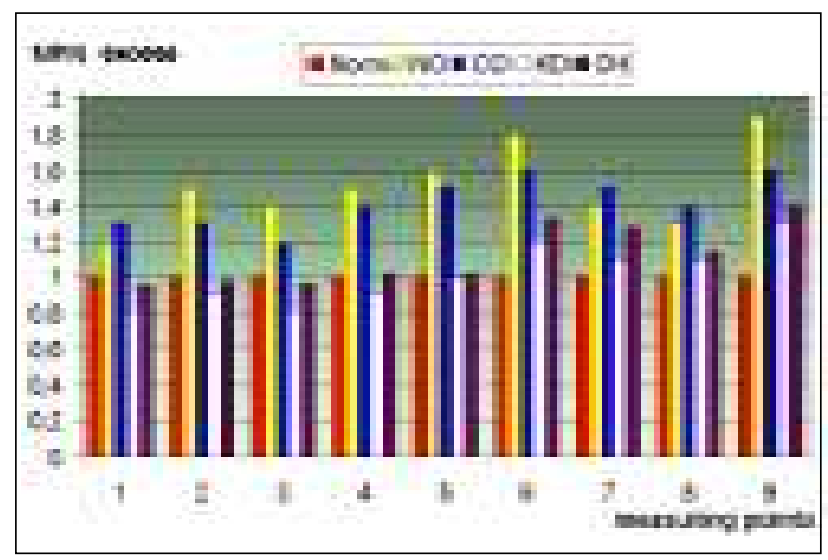

Fig 2. Overrun of substance concentrations at Ateities and L.Giros str parking-lot

The diagram shows that nitric oxide overran the highest permitted concentrations up to 1,9 times, which was the highest overrun compared with other substances. The lowest overrun of the highest permitted concentrations was seen in the case of dust (particle matter); at some measuring points within the area of the facilities dust concentration did not overrun the permitted level. At several measuring points (No 1, No 2 and No 3) hydrocarbon concentration did not overrun the permitted norms either.

The measurement results allow to draw a conclusion that the neighbouring Ateities and L. Giros streets have a heavy impact on the air pollution at this guarded parking-lot. Cargo and special vehicles parked in the parking area in question accounts for the major part of air pollution.

Of the guarded parking-lots intended for more than 100 cars, the lot located on Architektu street was chosen for study (Fig 3).

Location of the guarded parking-lot. On the northeastern side, a 12-storey residential building is located 10 meters away from the lot. On the southeastern side, a grove is located. On the southern side, a 12-storey residential house is located. On the western side, a grove and a 5-storey residential building are located approximately 


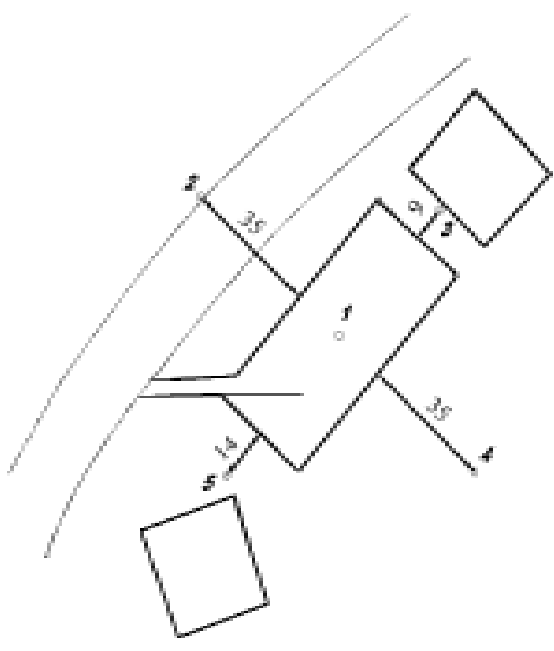

Fig 3. Guarded parking-lot on Architektų str

60 meters away from the lot. This house is separated from the lot by Architektu street. Underground garages are built under $3 / 4$ of the lot. Part of the lot (on the side of Architektu street) is planted with deciduous trees. The mean concentrations of hydrocarbons fluctuate from $3,12 \mathrm{mg} / \mathrm{m}^{3}$ to $3,56 \mathrm{mg} / \mathrm{m}^{3}$, of nitric oxide - from $0,068 \mathrm{mg} / \mathrm{m}^{3}$ to $0,084 \mathrm{mg} / \mathrm{m}^{3}$, of carbon monoxide - from $4,5 \mathrm{mg} / \mathrm{m}^{3}$ to $5,1 \mathrm{mg} / \mathrm{m}^{3}$, and of dust - from $0,07 \mathrm{mg} / \mathrm{m}^{3}$ to $0,11 \mathrm{mg} / \mathrm{m}^{3}$.

During the investigation the highest pollutant concentrations were found at the measuring point 2 , which was $30 \mathrm{~m}$ away from the lot, on the other side of Architektu street. At that point, the concentration of hydrocarbons was $3,56 \mathrm{mg} / \mathrm{m}^{3}$, of nitric oxide $0,084 \mathrm{mg} / \mathrm{m}^{3}$, of carbon monoxide $-5,1 \mathrm{mg} / \mathrm{m}^{3}$ and of dust (particle matter) $-0,11 \mathrm{mg} / \mathrm{m}^{3}$. The lowest concentrations were seen at the measuring point 4 . This point was at the biggest distance away form Architektu street, besides, no potential air pollution sources were found on the other side of the measuring point 4 , as a grove was located there.

The concentrations measured at the remaining points (No 3 and No 5) were similar. At the measuring point, concentrations slightly overran those at the measuring point 3 , as this measuring point was located closer to the entrance into the parking-lot.

The diagram in Fig 4 shows the distribution of pollutant concentrations at the measuring points.

The diagram shows that pollutant concentrations did not overrun the permitted norms set in hygiene requirements, except the concentration of carbon monoxide (CO) at the measuring point 2 ( $2 \%$ overrun). This could be explained by the fact that the increase in concentrations at this measuring point was also determined by motor transport passing along Architektų street.

The guarded parking-lot located on Č. Sugiharos street (Fig 5) was chosen due to the fact that the investigation results on that lot were not influenced by any other factors. No streets with heavy traffic, residential houses or other buildings and potential sources of pollu-

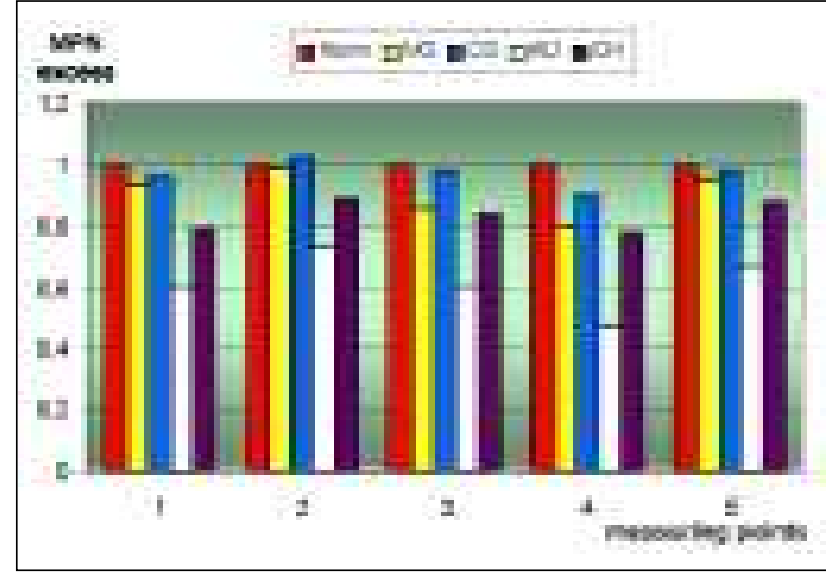

Fig 4. Overrun of substance concentrations at a guarded parking-lot on Architektų str

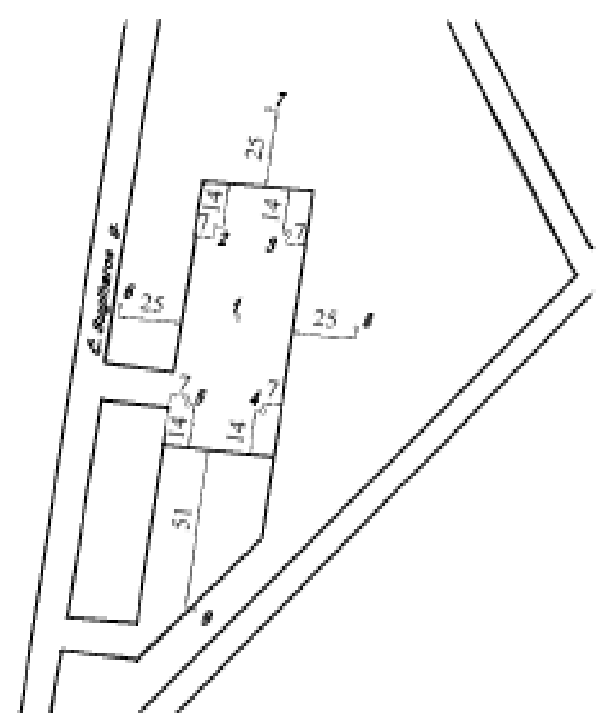

Fig 5. Guarded parking-lot on Č. Sugiharos str

tion were found close to the lot. Thus, the results of the investigation carried out at that lot revealed the pollution level only at the parking-lot in question. The mean concentrations for hydrocarbons fluctuated from $1,93 \mathrm{mg} / \mathrm{m}^{3}$ to $2,46 \mathrm{mg} / \mathrm{m}^{3}$, for nitric oxide - from $0,065 \mathrm{mg} / \mathrm{m}^{3}$ to $0,080 \mathrm{mg} / \mathrm{m}^{3}$, for carbon monoxide - from $3,2 \mathrm{mg} / \mathrm{m}^{3}$ to $4,8 \mathrm{mg} / \mathrm{m}^{3}$ and for dust - from $0,04 \mathrm{mg} / \mathrm{m}^{3}$ to $0,09 \mathrm{mg} / \mathrm{m}^{3}$.

The highest permitted pollutant concentrations were found at the measuring point 5 . This measuring point was located at the closest distance from the entrance (exit) in the lot, so the number of passing vehicles was the highest there. The lowest pollution concentrations were found at the measuring points 8 and 9 . The latter measuring point was most far away from the area under study, i e 50 meters away. The measuring point 8 was located 25 meters away from the lot, and it was rather 


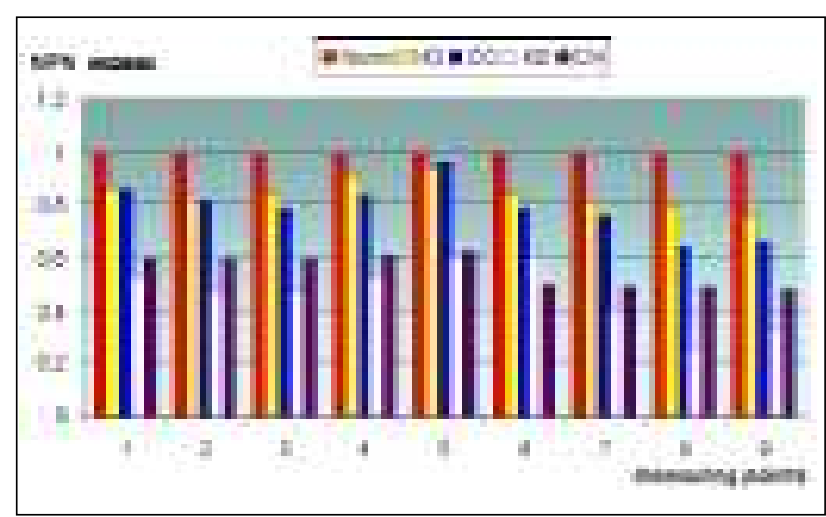

Fig 6. Overrun of substance concentrations at a guarded parking-lot on Sugiharos str

close to the grove. At the remaining points similar concentrations were observed.

The measurement results reveal that the highest permitted concentrations were not overrun at any point. Pollution concentrations are seen on the diagram below (Fig 6).

A conclusion on the impact of parking-lots of Vilnius on air pollution might be drawn from the results of pollution concentration measurements at typical guarded parking-lots. From the obtained findings, it is evident that the concentration of pollutants - hydrocarbons, carbon monoxide and nitric oxide - at the crossroad of Ateities and L. Giros streets overran the permitted hygiene norms, while dust concentrations were almost within the required norms. The measurements carried out at the parking-lots located on Architektu and $\breve{C}$. Sugiharos streets show that pollutant concentrations did not overrun the permitted hygiene norms and were lower than those at the parking-lots near the crossroad of Ateities and L.Giros streets. Most of the pollutant concentrations measured were influenced by streets located in close vicinity of parking-lots as well as by the type of vehicles parked there. The closer was a street and the heavier traffic it had, the higher were pollutant concentrations. Higher concentrations of pollutants were observed in areas where heavy or special vehicles were parked as well as at entrances into parking-lots. The highest overrun was observed when measuring carbon monoxide and nitric oxide. Hydrocarbons and dust concentrations did not overrun the permitted hygiene requirements and only at the measuring points located close to streets they were slightly higher.

\section{Conclusions}

1.The investigation results reveal that the concentrations of pollutants - hydrocarbons, carbon monoxide and nitric oxide - overran the permitted hygiene norms almost twice (nitric oxide - 1,9 times, carbon monoxide - 1,6 times, and hydrocarbons - 1,4 times), while dust concentrations in the atmosphere were almost within the permitted hygiene norms.

2. Measuriements carried out on Architektu and Č. Sugiharos streets reveal that pollutant concentrations did not overrun the permitted hygiene requirements (mean concentrations for hydrocarbons are $1,98 \mathrm{mg} / \mathrm{m}^{3}$, for nitric oxide $-0,071 \mathrm{mg} / \mathrm{m}^{3}$, for carbon monoxide $3,8 \mathrm{mg} / \mathrm{m}^{3}$ and for dust $-0,06 \mathrm{mg} / \mathrm{m}^{3}$ ).

3. Streets located in close vicinity of parking-lots had the highest influence on pollutant concentrations; besides, the concentrations depended on the type of vehicles parked.

4. Higher concentrations of pollutants were observed in the areas where heavy or special vehicles were parked as well as at entrances into parking-lots.

5. The highest overrun of the permitted concentrations was observed in the case of carbon monoxide and nitric oxide. On the average, carbon monoxide overran the permitted concentrations 1,2 time, and nitric oxide 1,1 time.

\section{References}

1. Šimaitis, R.; Baltrènas, P. Concentration of air contaminants in Vilnius and its impact on human health. Environmental Engineering (Aplinkos inžinerija), Vol X, No 1. Vilnius: Technika, 2002, p Ia-If (in Lithuanian).

2. Is the environmental performance of the transport section improving? Indicators tracking and environment integration in the European Union. European Environment Agency - TERM 2001.

3. Ilgakojyte, J.; Baranas, Ž. Envinronmental control systems of transport. Transport (Transportas), 2000. Conference proceedings. Vilnius: Technika, 2000 (in Lithuanian).

4. Aplinka. LR aplinkos m-ja. Environment. Ministry of Environment of the Republic of Lithuania. Vilnius, 2001.

5. Baltrènas, P.; Ožkinis, V.; Zigmontienè, A.; Paliulis, D. Investigation of air pollution at metal garage places in Vilnius city. Environmental Engineering (Aplinkos inžinerija), Vol VIII, No 2, Vilnius: Technika, 1998, p 57-65.

6. Vasarevičius, S.; Mačernius, A. Investigation of pollutant emissions from motor transport on streets in Vilnius. Journal of Environmental Engineering and Landscape Management, Vol XI, No 2, Vilnius: Technika, 2003, p 54-59. 


\section{ORO TARŠA VILNIAUS AUTOMOBILIU STOVĖJIMO AIKŠTELĖSE}

\section{P. Baltrènas, D. Kaziukonienė, M. Kvasauskas}

\section{S antrauka}

Vilniui plečiantis, kyla vis didesnis nauju automobilių parkavimo vietų poreikis. Šiai problemai spręsti gali būti irengtos saugomos automobilių aikštelès arba, siekiant kuo mažesnių naudingos žemès sąnaudų ir laikantis gamtosauginių reikalavimų, požeminiai ar kelių aukštų šiuolaikiniai garažai.

Tyrimai buvo atliekami Vilniaus automobilių stovejjimo aikštelèse. Visos saugomos automobilių stovejjimo aikštelès suskirstytos į tipus pagal jose laikomo transporto tipą ir aikštelių dydi. Matavimams pasirinkta po vieną kiekvieno tipo aikštelę. Nustatyta angliavandenilių, azoto oksido, anglies monoksido ir dulkių koncentracijos.

Tyrimams pasirinktos saugomos automobiliu stovèjimo aikštelès prie Ateities ir L. Giros gatvių sankryžos, Architektų bei Č. Sugiharos gatvèse. Ateities ir L. Giros gatvių sankryžoje esančioje aikšteleje didžiausios azoto oksido koncentracijos (leistinąsias viršija iki 1,9 karto). Leistinąsias koncentracijas viršija ir anglies monoksidas bei angliavandeniliai. Mažiausios reikšmès nustatytos išmatavus dulkių koncentracijas atmosferos ore.

Raktažodžiai: oro tarša, mobilieji taršos šaltiniai, anglies monoksidas, azoto oksidas, angliavandeniliai, dulkès.

\section{ЗАГРЯЗНЕНИЕ ВОЗДУХА НА ПЛОЩАДКАХ АВТОМОБИЛЕЙ В Г. ВИЛЬНЮСЕ}

\section{П. Балтренас, Д. Казюконене, М. Квасаускас}

Р ез ю е

В связи с расширением города Вильнюса возникает все большая нужда в новых местах для парковки автомобилей. Чтобы решить эту проблему, можно строить охраняемые площадки для автомобилей или подземные гаражи в несколько этажей, добиваясь использования минимальной полезной площади и придерживаясь природоохранных требований.

В целях исследования все охраняемые площадки для автомобилей Вильнюса были разделены по типам транспорта и размерам. Для измерений было выбрано по одной площадке каждого типа - на улицах Атейтес, Л. Гирос, Архитекту и Ч. Сугихарос. Измерялись концентрации окиси азота, моноксида углерода и пыли. Самые большие концентрации окиси азота были зарегистрированы на площадке у перекрестка улиц Атейтес и Л. Гиры. Концентрации моноксида углерода и углеводорода превышали допустимые нормы, а концентрация окиси азота превышала норму даже в 1,9 раза. Самой маленькой была концентрация пыли в воздухе атмосферы.

Ключевые слова: загрязнение воздуха, мобильные источники загрязнений, моноксид углерода, углеводород, пыль. 